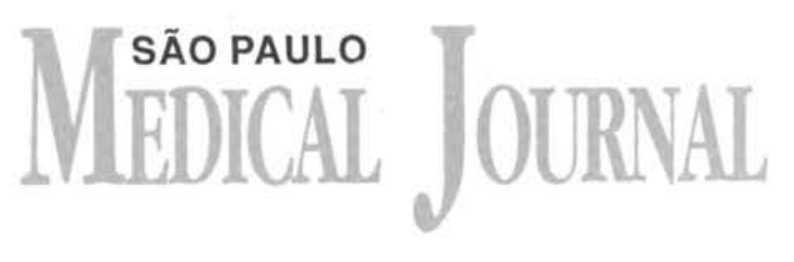

\title{
Progressive muscular dystrophy - Duchenne type. Controversies of the kinesitherapy treatment
}

\author{
Work carried out at the Section of Physiatrics and at the Myopathy Section (SM) of INDC-UFRJ \\ (Deolindo Couto Neurological Institute - Rio de Janeiro Federal University) - Rio de Janeiro, Brazil
}

The authors carried out a study of children with progressive muscular dystrophy of Duchenne type (DMD), giving special attention to physiatrical follow-up, having in mind that the practice of exercises has been debated very much in the specialized literature. The goal of this study is to try to settle the limits for the utilization of kinesitherapy which should be applied only in specific situations, such as: after skeletal muscular trauma or when the respiratory system is at risk. In this situation the physiatrical procedure would be to restrict physical activity, with early use of wheelchairs and the exclusion of the use of orthoses for orthostatism. DMD, at present, has been considered a result of duplication $(60 \%)$, deletion (5 to $6 \%$ ) or point mutations at gen Xp21 (Zatz, 1994), that codifies a protein called Dystrophin ( Hoffman et al., 1987). Dystrophin is a cytoskeletal sarcolemmic protein that constitutes about .002\% of the total protein of the muscle, present in skeletal fibers concentrated in muscle tendinous joints, which supplies mechanical reinforcement to the surface of the membrane during stretching and shortening physical activity. This protein is absent in DMD cases, wherefore, the sarcolemma undergoes a segmentary necrosis losing its contractile property during eccentric and concentric physical activity. The importance of physiatrical follow-up for DMD patients is to avoid deformities and tendon shortening, to ameliorate the patient's quality of life, to provide respiratory assistance and general couseling to members of the patient's family. The objective of this study is to try to clarify the risks and possibilities of kinesitherapy applied to DMD cases.

UNITERMS: Neuromuscular disease. Duchenne muscular dystrophy

\section{MATERIAL AND METHODOLOGY}

$\mathrm{T}$ Ten boys from 6 to 12 years of age were diagnosed as DMD bearers, and were treated at the Myopathy Section and at the Section of Physiatrics of Deolindo Couto Neurology Institute - Rio de Janeiro Federal University. Of the children receiving outpatient

\author{
Address for correspondence: \\ Ana Valeria de Araujo Leitão \\ Rua Paulo Cézar de Andrade, 200 - Ap. 702 \\ Parque Guinle - Laranjeiras \\ Rio de Janeiro/RJ - Brasil - CEP 22221-090
}

treatment, two were bedridden and the others had already tendon retractions of the lower limbs, enlargement of the calves, toe walking and those less affected presented waddling gait. (Fig. 1 and Fig. 2).

Calcium regulators, cardiological follow-up and respiratory function tests were applied in all cases. Taking the specialized medical literature as basis (Kakulas \& Mastaglia, 1990), we excluded resistance exercises, stretching of contracted structures, passive mobilization of body segments. On the other hand, when loss of ambulation occurred we prescribed orthose, postural assistance and avoidance of muscular fatigue. At the same time, we organized a home program of moderate physical activities which involved school and recreational occupations; stretching exercises were also included. 


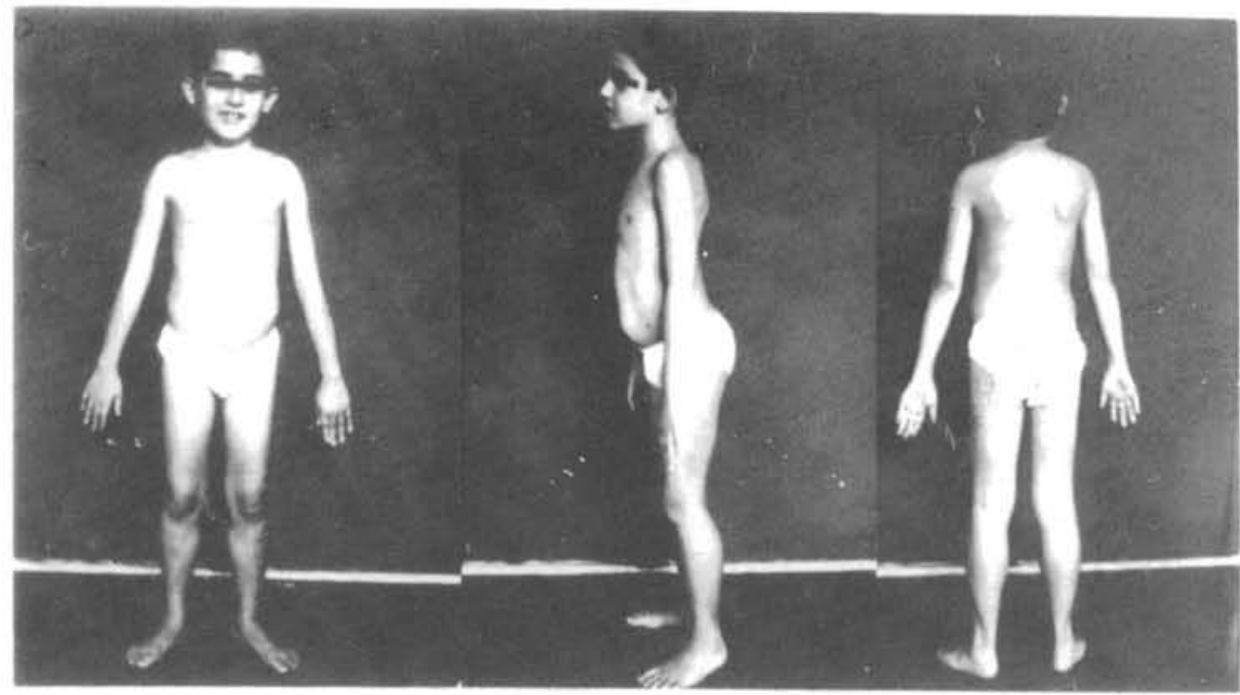

Figure 1

transference to become bedridden. Furthermore, two boys were already bedridden during the last few years; in a more advanced stage of this study, the number of children with unfavourable development totalized 4 (see table 1).

Family members were counseled, as to the risks of physical effort and the reasons for the non prescription of exercises, however only one of the boys has regularly attended a heated swimming pool, every other day, without showing any signs of worsening of his clinical picture. We have been studying the possibility of surgical correction through a percutaneous Achilles tenoto-

\section{RESULTS}

We observed that the removal of kinesitherapy from some children affected with waddling gait and Gowers' sign (tripoding) resulted in the lessening of muscle fatigue and consequently improvement of physical performance, quality of ambulation as well as the skill of walking up stairs (according to the Archibald and Vignos Scale, 1959). The precaution of avoiding fatigue and the removal of kinesitherapy from children affected by waddling gait and toe walking kept the level of endangered muscles stable, that is, without any unfavourable progression during the last three or four years, except for two eight-year-old boys, one of them having evolved from waddling gait to toe walking and then later to transference and the other from my, on those children who are beginning to have an inadequate posture and that need orthoses while at the ambulation stage, and not later when they become unable to ambulate or when they become confined to a wheelchair.

\section{DISCUSSION}

We wish to point-out that this is a preliminary report on research that is still being developed, but at this stage it has already allowed us to perceive that the restriction of physical activity, exclusion of conventional kinesitherapy

\begin{tabular}{|c|c|c|c|c|c|c|}
\hline \multicolumn{7}{|c|}{ Table 1} \\
\hline Age & $\begin{array}{l}\text { Anserine } \\
\text { gait }\end{array}$ & $\begin{array}{l}\text { Digitigrade } \\
\text { gait }\end{array}$ & Trasference & Bedridden & $\begin{array}{l}\text { Favorable } \\
\text { evolution }\end{array}$ & $\begin{array}{l}\text { Unfavorable } \\
\text { evolution }\end{array}$ \\
\hline 6 years & $x$ & & & & $x$ & \\
\hline 6 years & & $x$ & & & $x$ & \\
\hline 7 years & $x$ & & & & $x$ & \\
\hline 8 years & $x$ & & & & $x$ & \\
\hline 8 years & & $x$ & & & $x$ & \\
\hline 8 years & & & $x$ & & & $x$ \\
\hline 8 years & & & & $x$ & & $x$ \\
\hline 10 years & $x$ & & & & $x$ & \\
\hline 11 years & & & $x$ & & & $x$ \\
\hline 11 years & & & & $x$ & & $x$ \\
\hline
\end{tabular}


and, specially the avoidance of muscle fatigue have, apparently, preserved a reasonable physical capability.

Accordinly to Kakulas and Mastaglia (1990), it is obvious that remarkable muscular alterations already occur during the fetal period. During childhood and adolescence, necrosis is present and in a high degree in certain muscle groups of the scapular and pelvic girdle, besides the occurrence of enlargement of the calves for reasons still unknown. This shows the early effects on our little patients' neuromotor system.

Nowadays, many authors agree that there is benefit in restricting eccentric stretching exercise, besides the avoidance of muscle fatigue. Elder et Sola (1990) suggest the carrying out of a clinical study concerning the effects of exercise on children affected with DMD. Byrne (1990) prescribed kinesitherapy specially in cases when the respiratory system was endangered and specifically in the 20 years-old group and after trauma. Dubowitz (1990) questioned whether active exercises would improve or produce degeneration in the patient's muscles affected with DMD and he concluded that moderate exercise can be beneficial when they were related to the residual power of developed muscles and that excessive exercise would cause damaging effects to the muscle fibers. However, this author did not define what moderate exercise meant. Werneck (1994) emphasized that the absence of Dystrophin in DMD cases resulted in loss of proteins associated with it in the sarcolemma, as well as the loss of connections between the subsarcolemal cytoskeleton and the intracellular

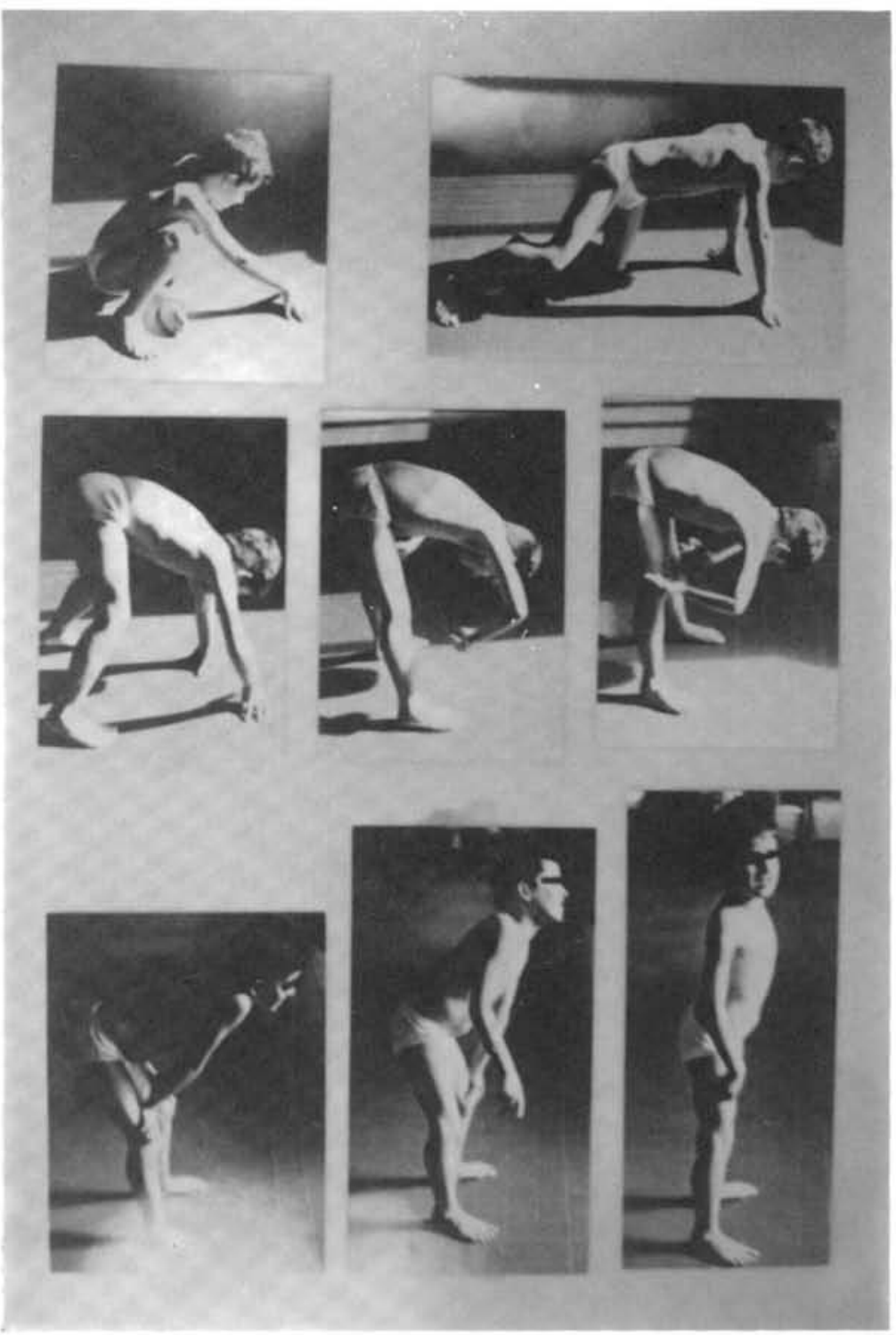

Figure 2 matrix; with the instability of the sarcolemma and sensitivity to trauma caused by exercise, there would be an overload of intramuscular calcium and necrosis of muscle fibers.

However, for most authors, the total suspension of physical activities would, at least, arouse psychological problems in the child, together with atrophy for the non use of his global musculature.

As ambulation becomes arduous there is the possibility of fiber necrosis taking charge of the sustainning muscles with a consequent unfavourable unfolding of the general picture, therefore, leading to the recommendation of the use of a wheelchair, relative rest and the avoidance of muscle fatigue, such as strolling long distances, going up slopes or stairways.

Concerning the use of electrotherapy, Law et Mc Comas (1990) performed simultaneous eletrical stimulation of the nerve supplying the muscle and the neuromuscular junction with implanted electrodes and radio frequency control. Through this work, they showed the occurrence of advanced degeneration of the musculature, similar to what was found when these patients underwent intensive exercise or stretching.

The results that would indicate the exclusion of eccentric contractions and the use of kinesitherapy have not yet been conclusive owing to the complexity of the contractile activity of muscle groups during body exercise and during different postures. However, for trauma 
recovery cases, isometric and shortening exercises can be recommended with great care and respiratory kinesitherapy when necessary.

The use of calcium regulators proved to be inefficient confirming the specialized literature which described the subjective improvement as greater than the clinical's.

We expect that with the introduction of physiology and kinesiology to these studies, research will turn up more light which will enable us to assume a position regarding the motor recovery programs of these patients.

\section{FINAL CONSIDERATIONS}

Taking the medical literature and our own observations as a basis we could perceive that DMD is a chronic disease, without acute stages, but develops into disability and finally death. However, this disappointing fact should not thwart the intervention of physiatrics and of a rehabilitation team concerning general assistance to these patients. As to the exercise program for DMD patients, general consensus recommends waiting for additional knowledge that will result from the inclusion of kinesiology in the research of physiopathology and genetics currently being developed.

\section{RESUMO}

Objetivos: Trabalho realizado em crianças com Distrofia Muscular tipo Duchenne (DMD), focalizando a atuação fisiátrica em razão da polêmica sobre os exercícios físicos nestes pacientes. Hoje, sabe-se que a DMD resulta de uma anomalia genética (Xp21) acompanhada da ausência de DISTROFINA, condição determinante da necrose do sarcolema e eliminaçāo de sua propriedade contrátil durante as atividades físicas. Material e Métodos: Foram atendidas 10 crianças DMD: 2 grabatárias e $8 \mathrm{com}$ sinais conspicuos da doença. Todas receberam bloqueadores de cálcio, atençäo cardiológica e respiratória. Excluiramse os exercicios resistidos, de estiramento de estruturas retraídas e mobilizaçōes passivas. Mantiveram-se: a órtese no momento de perda da deambulaçāo, a assitência postural e a prevenção de fadiga. Mas, estabeleceu-se um programa domiciliar de atividades físicas escolar e recreativa moderadas, e exercícios de alongamento realizados de forma cautelosa. Resultados e conclusão: A exclusāo da cinesioterapia e a restriçāo de atividades físicas extenuantes atenuaram a fadiga muscular e melhoraram a marcha, mantendo-se a capacidade física razoável em oito crianças. A atençāo fisiátrica às crianças com DMD previne os encurtamentos tendinosos, melhora a qualidade de vida, presta assistência respiratória e orienta os familiares. Atualmente, muitos autores concordam sobre a vantagem da restrição de exercicios e da prevençāo da fadiga muscular. Entretanto, aguardam-se mais esclarecimentos após a inclusāo da cinesiologia nas pesquisas que estão em andamento. 


\section{REFERENCES}

1. ARCHIBALD, K. C. ET VIGNOS JR., P. (1959) - The Clinical Management of Muscle Disease. apud Siegel, I . M., London, William Heinemann Medical Books, 1977, pp. 89-91,

2. BERTORINI, T. E.; PALMIERI, G. M. A.; BROWN, R.; NUTTING, D. F.; KARAS, J. G. - Effect of chronic treatment with the calcium antagonist diltiazem in Duchenne muscular dystrophy. J of Neurol 38: 609-613, 1988.

3. BYRNE, E. - Dystrophin input of a neurologist. in: B. A. Kakulas et F. Mastaglia: Pathogenesis and Therapy of Duchenne and Becker Muscular Distrophies. Raven Press, New York, 1990, pp. 137-138.

4. BULLER, A. J.; GOODFELLOW, J. et NEWSOM-DAVIES, J. M. - Management of children: Pharmacological and Physical. British Medical Bulletin 45(3): 788-801, 1989.

5. ELDER, G. et SOLA, O. M. - Past Therapeutic Trials and Current Corrective Procedures, in: B. A. Kakulas et F. Mastaglia: Pathogenesis and Therapy of Duchenne and Becker Muscular Distrophies. Raven Press, New York, pp. 217, 1990.

6. HILLER, L. B.; WADE, C. K. - Upper extremities functional assessment scales in children with Duchenne Muscular Dystrophy: a comparison. Archives of Phys Med \& Rehab, 73(6): 527- 534, 1992.
7. HOFFMAN, E. P.; BROWN, E. P. et KUNKEL, L. M. Dystrophin: the protein product of the Duchenne Muscular Dystrophy locus. Cell 51: 919-928, 1987.

8. DUBOWITZ,V. - Physical therapy in neuromuscular disorders. Journal of the Neurological Sciences 98 (Supp): 29-30, 1990.

9. KAKUlas, B. A. et MAStAGliA, F. L. - Pathogenesis and Therapy of Duchenne and Becker Muscular Distrophies. Raven Press, New York, 1990.

10 LAW, P. K. - Summary: Past Therapeutic Trials, in: Pathogenesis and Therapy of Duchenne and Becker Muscular Distrophies. Raven Press, New York, 1990, pp. 216-217.

11. SIEGEL, I. M. - The Clinical Management of Muscle Disease. William Heinemann Books LTD, London, 1977, pp. 89-91.

12. WELLER, B.; KARPATI, G.; CARPENTER, S. - Dystrophin deficient MDX muscle fibers area preferentially vulnerable to necrosis induced by experimental lenghthening contraction. J. of Neurologic Sciences 100: 9-13, 1990.

13. WERNECK, L. C. - Perspectivas em doenças neuromusculares: 1. Distrofia muscular de Duchenne. Rev Bras Neurol 30(2): 33-35, 1994.

14. ZATZ, M. et al. - O impacto da biologia molecular na compreensão e prevenção das miopatias hereditárias. Rev Bras Neurol 30(2): 41-44,1994. 